\title{
Między demokratyzmem a autorytaryzmem - kształtowanie się programu politycznego PPS przed i po maju 1926 roku
}

Szczególną cechą poglądów ustrojowych Polskiej Partii Socjalistycznej w okresie od rewolucji 1905 roku do wydarzeń maja 1926 roku była fundamentalna zmiana w doborze metod i środków służących realizacji postulatów programowych tego ugrupowania. Polska Partia Socjalistyczna była bez wątpienia jednym z najważniejszych współtwórców systemu politycznego odrodzonego w 1918 roku państwa polskiego. Ponadto, z jednej strony, w programie politycznym u progu niepodległości podkreślała konieczność osiągnięcia porządku socjalistycznego w stopniowym rozwoju państwa o ustroju parlamentarno-gabinetowym, z drugiej zaś, pozostając pod przemożnym wpływem osobowości Józefa Piłsudskiego, w działaniu krótko poparła zbrojne wystąpienie piłsudczyków w 1926 roku.

Przedmiotem artykułu nie jest wszak ukazanie stosunku PPS do zamachu stanu Józefa Piłsudskiego, ale przybliżenie jej poglądów na demokratyczny i autorytarny model sprawowania władzy w kontekście zamachu majowego i rządów sanacji*. Poglądy te znajdowały swoje odzwierciedlenie zarówno w obowiązującym programie politycznym ugrupowania, jak i w politycznych deklaracjach liderów. Artykuł ukazać ma kwestie wyboru sposobu realizacji celów kluczowego ugrupowania politycznego lewicy w kontekście objęcia władzy w Rzeczypospolitej przez obóz Józefa Piłsudskiego.

Zaznaczyć należy, że rewolucjonizm w poglądach ustrojowych PPS zasadniczo kończy się na rewolucji 1905 roku. Nie odrzucając oczywistego faktu, że po-

* Autor przybliżył tę kwestię w artykule: Stanowisko Polskiej Partii Socjalistycznej wobec zamachu majowego w 1926 roku, „Studia nad Autorytaryzmem i Totalitaryzmem” 40, 2018, nr 2, s. $103 \mathrm{n}$. 
rzucenie drogi rewolucyjnej przez nią wynikało z porażki ogólnokrajowego zrywu, to również miało istotny wpływ na poglądy Józefa Piłsudskiego w kwestii określenia przez partię dalszego programu niepodległościowego. Podkreśla się, że:

Klęska rewolucji 1905 r. oznaczała zarazem porażkę jego koncepcji (skierowania partii robotniczej do działań powstańczych). Uznał wówczas, że powstanie zbrojne musi oprzeć się na wszystkich siłach społecznych. Pozostając nadal na pozycji demokratycznej, zaczął ujmować państwo w sposób ponadklasowy, ogólnonarodowy ${ }^{1}$.

Odejście od idei rewolucji nie miało wszakże charakteru absolutnego, albowiem funkcjonujące w obrębie partii pomniejsze frakcje wielokrotnie występowały z koncepcjami bliskimi rewolucjonizmowi, choć odgrywały rolę marginalną. Owo odejście przez ugrupowanie od metod stricte rewolucyjnych: strajki protestacyjne i powszechne, walki uliczne, akcje bojowe, ekspropriacje czy też wysadzanie mostów, miało charakter stopniowy. Na powolne zastępowanie metod rewolucyjnych przez partię działaniami o charakterze politycznym wskazywała między innymi już Anna Żarnowska: ,zaczynają się pojawiać [od 1906 roku — przyp. W.K.] na łamach »Robotnika« artykuły dyskusyjne [...] zwracające uwagę na przedłużanie się rewolucji i idącą z tym w parze depresję mas"2. Odejście od metod rewolucyjnych miało być kompensowane odstąpieniem od bojkotu wyborów do II Dumy. Walka parlamentarna zdaniem części kierownictwa PPS miała umożliwić większą agitację polityczną wśród wyborców i skuteczniejszą realizację celów programowych ugrupowania aniżeli brawurowe akcje Wydziału Bojowego. Warto dodać, że Polska Partia Socjalistyczna była najważniejszym ugrupowaniem politycznym okresu dwudziestolecia i jednocześnie najsilniejszym ugrupowaniem robotniczym na scenie politycznej.

Analizując tytułowe zagadnienie z punktu widzenia doktrynalnego, podkreślić należy, że program PPS od marca 1907 roku nosił już cechy programu reformistycznego i ewolucjonistycznego, nie zaś rewolucyjnego. Świadczy o tym między innymi zapowiedź dążenia do ustanowienia „niepodległej demokratycznej republiki polskiej”, co expressis verbis wskazano w opublikowanej na łamach „Robotnika” deklaracji autorstwa liderów PPS Frakcji Rewolucyjnej. Podkreślić trzeba, że liderzy wówczas konkurencyjnego, rozłamowego, ugrupowania PPS Lewicy tego punktu w swoim programie nie mieli, co z czasem stało się powodem ich politycznej marginalizacji. Wskazać też trzeba na swoisty paradoks — partia ze słowem „rewolucyjna” w nazwie wskazywała, że o ile wywalczenie niepodległości nastąpi w wyniku walki zbrojnej, to już cele programowe socjalistów realizowane będą w powolnej ewolucji ustroju demokratycznego. Już w roku 1896 podczas tak zwanego zjazdu londyńskiego w ramach działań II Międzynarodów-

1 E. Pejaś, Myśl polityczna Kazimierza Czapińskiego w latach 1918-1939, Warszawa 2017, s. $100-101$.

2 A. Żarnowska, Geneza rozłamu w Polskiej Partii Socjalistycznej 1904-1906, Warszawa 1965, s. 439. 
ki działacze Polskiej Partii Socjalistycznej opowiadali się za niepodległością Polski. Zaznaczono, że:

II Międzynarodówka stała się również wygodną platformą do przenoszenia koncepcji socjalistycznych, opierając się na niej, można było lansować także własne interesy narodowe. Starali się tak czynić działacze z PPS, którzy podczas zjazdu londyńskiego w 1896 r. postanowili przyjąć do programu międzynarodowego socjalizmu postulat niepodległości Polski, podnosząc jej suwerenność narodową jako hasło mające połączyć europejski ruch polityczny³.

Zmiany programowe następowały szybko, albowiem już trzy lata po rewolucji 1905 roku na czoło postulatów politycznych partii wysuwała się zapowiedź dążenia do kolejnej rewolucji, aczkolwiek szczególnej i bezkrwawej. Socjaliści chcieli się posłużyć tak zwaną rewolucją socjalną. Ich zdaniem miała ona umożliwić stopniowe realizowanie celów ugrupowania, z których za szczególnie istotny w realizacji swoich zamierzeń politycznych uznawali zniesienie prywatnej własności środków produkcji. Warunkiem sine qua non zaistnienia rewolucji socjalnej miało być zdobycie władzy politycznej.

dążeniem naszym powinno być zdobycie jak największej swobody politycznej, zrobienie państwa jak najbardziej demokratycznym (zdemokratyzowanie go). [...] w interesie ludu pracującego leży, żeby państwem nie rządził monarcha [...], ale żeby była zaprowadzona republika, rządził zaś parlament i to taki, który by był wybrany przez cały naród, czyli za pomocą głosowania powszechnego. W parlamencie są uchwalane prawa, od których los całej ludności zależy, trzeba zatem mieć możność wywierania nań jak największego wpływu [...] Jednym słowem, w interesie naszym leży, żeby państwo było jak najbardziej demokratyczne $[\ldots]^{4}$.

Tak więc rewolucja socjalna potrzebowała do swojego istnienia systemu demokracji parlamentarnej. Cytat ten obrazuje więc inny istotny postulat, mianowicie dążenie do odzyskania niepodległości. Potrzeba stworzenia niepodległego państwa, wraz z realizacją programu socjalnego, zajmowała w stanowisku partii istotne miejsce przed listopadem 1918 roku, wytworzyła się zaś zasadniczo po doświadczeniach rewolucji 1905 roku. Artur Leinwald pisał nawet, że na obszarze tak zwanej dawnej kongresówki „PPS była jedyną zorganizowaną siłą polityczną, która propagowała hasło niepodległości, krzewiła świadomość narodową wśród robotników i mas pracujących, uzasadniała potrzebę walki o własne pań-

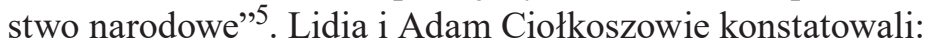

3 W. Potkański, Terroryzm na usługach ugrupowań lewicowych i anarchistycznych w Królestwie Polskim do 1914 roku, Warszawa 2014, s. 57.

4 A. Wroński, Objaśnienie programu Polskiej Partii Socjalistycznej, Kraków 1908, s. 29-31.

5 A. Leinwald, PPS a sprawa niepodległości Polski, [w:] Stulecie polskiej partii politycznej 1892-1992, red. M.M. Drozdowski et al. Warszawa 1993, s. 39. Znaczenie hasła niepodległości państwa w programie lewicy podkreśla też Stanisław Michałowski w kontekście konieczności utworzenia przyszłych sił zbrojnych. Zauważa, że bez rozgrywania karty niepodległościowej nie doszłoby do powstania między innymi Związku Walki Czynnej czy też Związku Strzeleckiego. Por. S. Michałowski, Idea niepodległego państwa w myśli politycznej Polskiej Partii Socjalistycznej (1892-1923), „Rocznik Lubelski” 33-34, 1991-1992, s. 43. 
Socjaliści polscy odrzucali stanowczo pogląd, jakoby sprawę wyzwolenia społecznego można było oddzielić od sprawy wyzwolenia politycznego oraz pogląd, jakoby wyzwolenie z niewoli społecznej samoczynnie usuwało wszystkie inne rodzaje niewoli i zależności. Toteż w swych wypowiedziach poświęcali wiele uwagi zagadnieniom typu ustrojowego przyszłego państwa polskiego ${ }^{6}$.

Niejako przy okazji toczonych rozważań w ślad za Władysławem T. Kuleszą nadmienić można, że w przypadku Józefa Piłsudskiego jego działalność w PPS i program partii jeszcze przed odzyskaniem niepodległości w ogóle przestały się liczyć. Marszałek skoncentrował się wyłącznie na postulacie niepodległości Rzeczypospolitej ${ }^{7}$. Znaczenie postulatów niepodległościowych w programie Polskiej Partii Socjalistycznej jeszcze w okresie poprzedzającym odrodzenie się Rzeczypospolitej podkreślał w swojej publicystyce między innymi znany śląski działacz PPS i późniejszy poseł na sejm II Rzeczypospolitej Tadeusz Reger ${ }^{8}$.

Postulat niepodległości do roku 1918 odgrywać będzie rolę zarówno decydującą, jak i różnicującą, powodując jednocześnie, że do PPS Frakcji Rewolucyjnej w sposób naturalny ciążyli tak znani działacze, jak Norbert Barlicki czy Stanisław Posner.

Nowy program polityczny PPS odrzucający rewolucjonizm określony został w marcu 1907 roku na zjeździe w Wiedniu. W programie zredagowanym przez Feliksa Perla akcentowano konieczność zasadniczego przekształcenia ustroju społecznego, uspołecznienie środków wytwarzania i komunikacji, w końcu utworzenie niepodległej i demokratycznej republiki polskiej. Gwarantem poprawy sytuacji gospodarczej i społecznej miała być „wszechstronna demokratyzacja” ustroju. Gdy doda się do tych celów jeszcze postulat utworzenia parlamentu na podstawie ordynacji wyborczej zakładającej wybory powszechne, równe, tajne i bezpośrednie oraz projektowanie dwustopniowego samorządu terytorialnego, widać wyraźnie, że hasła rewolucyjne stały się przeszłością. Ten demokratyczny reformizm, jak można by go określić, obowiązywał w partii również po 1918 roku.

Dokumentem świadczącym o przekształceniu się PPS w ugrupowanie dążące do osiągnięcia celów politycznych w stopniowej ewolucji ustroju jest między innymi publikacja Witolda Jodko-Narkiewicza Objaśnienie programu Polskiej Partii Socjalistycznej ${ }^{9}$. Wskazywał on, że cele socjalistów, jakkolwiek rewolu-

6 A. Ciołkosz, L. Ciołkosz, Zarys dziejów socjalizmu polskiego, Londyn 1972, t. 2, s. 619.

7 W.T. Kulesza, Koncepcje ideowo-polityczne obozu rzadzacego w Polsce w latach 1926 1935, Wrocław 1985, s. 64-65.

8 T. Reger, Socjaliści a niepodległość Polski, Kraków 1919, s. 5 n. Autor wskazywał tam między innymi że „niezbędną częścią składową demokracji jest niepodległość narodowa”, s. 11. Egzemplifikacją znaczenia postulatu niepodległości w programie partii może być treść odezwy Warszawskiego Okręgowego Komitetu Robotniczego Polskiej Partii Socjalistycznej z 3 maja 1916, w której podkreślono, że dążenia niepodległościowe są w programie ugrupowania najważniejsze. Zob. Towarzysze! Obywatele! Warszawa ma uczcić obchodem uroczysta rocznicę 3 Maja!, druk ulotny, Warszawa 1916.

9 W. Jodko-Narkiewicz, Objaśnienie programu Polskiej Partii Socjalistycznej, Kraków 1908. 
cyjne w swej treści dla burżuazji, winny być realizowane w wyniku stopniowych przemian społeczno-ustrojowych, bez cienia rewolucyjnej żywiołowości. Stąd też liczne podkreślenia w tekście, uwypuklające znaczenie zdobycia przez ugrupowanie legalnej władzy politycznej i konieczność realizacji celów społecznych. „Rewolucja socjalna — pisał Jodko-Narkiewicz — do której partia nasza dąży, różni się zasadniczo od wszystkich rewolucji dokonanych lub rozpoczynanych dawniej przez różne klasy" ${ }^{10}$. Hasło rewolucji zastępowane było postulatem zdobycia władzy politycznej, wszakże w ramach ustroju demokratycznego. Idee socjalistyczne mogą zostać zrealizowane jedynie w ramach republiki demokratycznej.

[W] interesie naszym leży, żeby państwo było jak najbardziej demokratyczne (ludowe) i o to powinniśmy wciąż niezmordowanie walczyć. Jeżeli do tego dodamy [...] że i ostateczny cel nasz — objęcie władzy politycznej — może być osiągnięty tylko wtedy, gdy zdobędziemy ustrój prawdziwie demokratyczny, to będziemy mieli obraz tego, do czego dążyć powinniśmy na polu politycznym. Celem tym powinno być uzyskanie republiki demokratycznej ${ }^{11}$.

Założenia ustroju przyszłego państwa wspomniane przez Witolda Jodko-Narkiewicza w 1908 roku zostały wyrażone między innymi w przyjętym przed wybuchem pierwszej wojny światowej programie ugrupowania. Program Polskiej Partii Socjalistycznej uchwalony w 1910 roku, jakkolwiek jeszcze odległy w swych założeniach od koncepcji politycznych formowanych w niepodległej Polsce, był programem, który pod względem treści głoszonych haseł nawiązywał z jednej strony do semantyki wypowiedzi o charakterze rewolucyjnym: „Jedynie wespół z klasą robotniczą miejską obali [włościanin — przyp. W.K.] panowanie kapitału i wielkiej własności ziemskiej"12. z drugiej zaś — w programie zawarto zapowiedź dążenia ugrupowania do ustanowienia ustroju stricte nawiązującego do rozwiązań charakteryzujących demokrację parlamentarną.

W tym samym kierunku - walki o prawa i wolności polityczne, o republikę demokratyczną — popycha klasę robotniczą rosnące w niej coraz bardziej poczucie godności ludzkiej i obywatelskiej, głód wiedzy, pragnienie dostępu do skarbów kultury, co z demokratyzacją życia politycznego ściśle się wiąże $\mathrm{e}^{13}$.

Socjaliści projektowali też w swym programie, by do czasu odzyskania przez Polskę niepodległości uzyskać w obrębie państwa rosyjskiego maksymalnie szeroką autonomię polityczną. Wyznacznikiem tej autonomii miało być zwołanie polskiej konstytuanty, której zadaniem, jak wiadomo, byłoby uchwalenie konstytucji. Ponadto planowano utworzenie niezależnej od państwa rosyjskiego legislatywy oraz odpowiedzialnej przed nią władzy wykonawczej ${ }^{14}$.

10 Ibidem, s. 25.

11 Ibidem, s. 31.

12 Program Polskiej Partii Socjalistycznej z 1910 roku, Warszawa 1910, s. 6.

13 Ibidem, s. 7.

14 Pomijając zapowiedź daleko idącej decentralizacji stosunków wewnątrz państwa rosyjskiego, skonstatować należy, że część postulatów programowych, wyrażonych w ówczesnym pro- 
Potwierdzenie haseł ewolucjonizmu i reformizmu zauważyć można też w poglądach liderów PPS po odzyskaniu niepodległości. Te zaś przekładały się na obowiązujący program partii. Miarodajnym barometrem nastrojów w PPS w kwestii wyboru drogi prowadzącej do ustroju socjalistycznego były partyjne kongresy. Na progu niepodległości, zarówno wśród liderów ugrupowania, jak i na niższych szczeblach partii panował wręcz chaos ideologiczny, jako że kwestia wyboru drogi prowadzącej do ustroju socjalistycznego pozostawała wciąż otwarta. Na ówczesną atmosferę panującą w partii wskazywał Kazimierz Więch:

Głównym zadaniem, które stawiała przed sobą partia, była przebudowa stosunków społecznych, przy czym jedni chcieli ten cel osiągnąć drogą reform, inni - walką rewolucyjną. Dla obu kierunków realizacja tego hasła wydawała się sprawą dość bliskiej przyszłości15.

Miarą stopnia załagodzenia wcześniejszych bezkompromisowych poglądów domagających się określenia stosunków społeczno-gospodarczych w wyniku rewolucji może być między innymi stosunek ugrupowania do Konstytucji 3 maja. O ile jeszcze w 1906 roku w odezwie adresowanej do członków Warszawskiego Komitetu Robotniczego pisano o konstytucji 1791 roku nie inaczej jak o „łataninie stosunków między chłopem a szlachtą"16, to już w roku 1916, w rocznicę jej uchwalenia, wskazywano, że „Konstytucja 3 Maja 1791 roku była dziełem najświatlejszych spośród szlachty" ${ }^{\prime 17}$.

Już podczas XIV zjazdu partii, odbywającego się w dniach 14-16 września 1918 roku w Warszawie, spośród kilku rozważanych kierunków polityki partii za zwycięski uznano model ewolucyjnego socjalizmu demokratycznego, którego zwolennikami byli między innymi Feliks Perl i Mieczysław Niedziałkowski. W ówczesnej atmosferze ideowej panującej w PPS liderzy ugrupowania byli przekonani, że należy się dystansować od dyktatury, będącej ich zdaniem nieefektywną. W debacie politycznej wskazywano na negatywny w tym zakresie przykład doświadczeń rewolucji rosyjskiej. Cele socjalistyczne, jak pisał Feliks Perl, osiągnięte zostać powinny w latach pracy, nie zaś — wprowadzeniem dekretów. Nie mniej zauważyć należy, że w toku obrad XIV zjazdu wśród uczestników zarysowała się jednak wyraźnie płaszczyzna sporu dotycząca konieczności wyboru między ową rewolucyjną władzą proletariatu a republiką demokratyczną o ustroju parlamentarno-gabinetowym jako formą pośrednią przed utworzeniem państwa socjalistycznego: „część działaczy lewicowych PPS [pisał M. Śliwa - przyp. W.K.] niechętnie ustosunkowała się do hasła republiki parlamentarnej i nawoły-

gramie Polskiej Partii Socjalistycznej miała charakter wręcz utopijny. Znakomitym tego przykładem było między innymi projektowanie tak daleko idącej autonomii ziem polskich wchodzących w skład państwa rosyjskiego.

15 K. Więch, PPS w pierwszych latach parlamentaryzmu 1921-1923, Warszawa 1987, s. 9.

16 Odezwa Warszawskiego Komitetu Robotniczego PPS z dnia 3 maja 1906 r., Warszawa 1906, druk ulotny.

17 Towarzysze! Obywatele! 
wała do przygotowań do rewolucji socjalistycznej, a w wyniku jej zwycięstwa do ustanowienia dyktatury proletariatu"18.

Ustalenia programowe XIV Zjazdu powtórzone zostały na pierwszym w niepodległej Polsce XV Zjeździe PPS w grudniu 1918 roku. Odrzucono ideę dyktatury proletariatu, mówiąc wprost — droga do socjalizmu ma wieść przez Sejm: „byli przekonani [socjaliści — przyp. W.K.], iż proces owej modernizacji Polski przeprowadzi się najlepiej w ramach ustroju sprawiedliwości społecznej”"19. Założenia reformistycznej doktryny socjalistów w ujęciu Feliksa Perla, zakładającej realizowanie celów ugrupowania w systemie demokracji parlamentarnej, scharakteryzował Tadeusz Reger. Według niego w programie powojennym ugrupowania czynnikami istotnymi w realizacji projektowanego ustroju socjalistycznego miało być dążenie do zwiększenia udziału przedstawicieli klasy robotniczej w sprawowaniu władzy zarówno na szczeblu parlamentu, jak i samorządu terytorialnego w połączeniu z dalszym procesem demokratyzacji prawa wyborczego:

[B]ez demokracji, bez udziału klasy robotniczej w rządach, zarówno w państwie, jak w samorządzie lokalnym, bez prawa wykonywania ze strony robotników kontroli nad dochodami i wydatkami państwa, kraju i gminy, jako też nad wykonywaniem ustaw przez urzędników, nie może być mowy o zdobywaniu trwałym, drogą ustawową, najkonieczniejszych reform socjalnych i szkolnych [...]. To też żądanie zaprowadzenia powszechnego głosowania i zdemokratyzowanie całego życia publicznego w państwie, w kraju i w gminie jest najważniejszą częścią wszystkich programów socjalistycznych ${ }^{20}$.

Analogicznie na XVII Kongresie Polskiej Partii Socjalistycznej w maju 1920 roku wprost wskazano, że proletariat nie może działać w sposób zagrażający bytowi dopiero co odrodzonego państwa.

Państwo polskie istnieje bez granic, wrogowie, oparci o stare, wrogie narodom potęgi, grożą młodej niepodległości; wszystko woła o współpracę, o twórczość spotęgowaną. Robotnik polski, socjalista polski o tę niepodległość walczył krwawo przez całe pokolenia, on tę Polskę budował i nie może tej budowy zaniechać w chwili wielkich dla niej niebezpieczeństw ${ }^{21}$.

Wśród współczesnych badaczy zwłaszcza Michał Śliwa podkreśla, że

większość socjalistów — przeświadczona o konieczności funkcjonowania w okresie przedsocjalistycznym demokratycznej formy państwa i organizacji społeczeństwa - wypowiadała się za oparciem ustroju odrodzonego państwa na zasadach demokracji politycznej i społecznej ${ }^{22}$.

Program polityczny przyjęty na ogólnokrajowym XVII Zjeździe Polskiej Partii Socjalistycznej akcentował porzucenie charakterystycznej dla wcześniejszych

${ }^{18}$ M. Śliwa, Dyktatura proletariatu w publicystyce i programach Polskiej Partii Socjalistycznej, „Czasopismo Prawno-Historyczne” 31, 1979, z. 1, s. 77.

19 M. Śliwa, Ludowcy i socjaliści w parlamencie II Rzeczypospolitej, Warszawa 1995, s. 23.

20 T. Reger, op. cit., s. 10.

21 XVII Kongres PPS, „Trybuna” 29 maja 1920, s. 626-627.

22 M. Śliwa, Polska myśl socjalistyczna 1918-1948, Wrocław 1988, s. 39. 
zjazdów zapowiedzi owej, bezpośredniej walki o socjalizm. Zygmunt Zaremba podkreślał, że wraz z chwilą odzyskania przez Rzeczpospolitą niepodległości doszło do koniecznego przeorientowania się uczestników zjazdu zarówno w aspekcie ideologicznym, jak i pragmatycznym. Porzucono dotychczasową taktykę polityczną, co spowodowane było koniecznością realizacji celów ugrupowania na forum Sejmu Ustawodawczego. Jego realia jak wiadomo, różniły się diametralnie od tych, w których zwykli działać wcześniej polscy socjaliści. Miejsce rewolucji społecznej zajął postulat przebudowy społecznej, głównym zaś miejscem walki politycznej stało się forum politycznie rozdrobnionego parlamentu. Zygmunt Zaremba podkreślał również skalę zaangażowania Związku Parlamentarnego Polskich Socjalistów w prace nad uchwaleniem konstytucji.

P.P.S. zgłosiła własny projekt wychodzący z oceny epoki jako przejściowej do socjalizmu, wprowadzający więc szereg przepisów i postanowień, określających takie reformy ustrojowe państwa, aby ewolucja w kierunku socjalizmu natrafiała na jak najmniejsze przeszkody. Zawierał więc ten projekt podważenie zasady własności prywatnej i poddanie wszelkich środków produkcji kontroli państwowej. [...] Obok Sejmu powstanie Izba Pracy, jako reprezentacja interesów robotniczych, a w każdym zakładzie przemysłowym powołane będą do życia Komitety Fabryczne [...]. Łatwość rozwiązywania Sejmu z inicjatywy 300 tysięcy obywateli, referendum ludowe i inicjatywa ustawodawcza, swobody obywatelskie i oddzielenie kościoła od państwa, zawarte w projekcie konstytucji, zgłoszonym przez P.P.S., miały zapewnić organizacji państwowej najbardziej demokratyczny charakter ${ }^{23}$.

Analizując program polskich socjalistów u progu niepodległego państwa, nie sposób pominąć ich wkładu w przygotowanie i zredagowanie Manifestu Tymczasowego Rządu Ludowego Republiki Polskiej ${ }^{24}$. Odnaleźć w nim można założenia programowe charakterystyczne dla reformistycznego i ewolucjonistycznego nurtu socjalizmu. Ze wspomnień Ignacego Daszyńskiego wynika, że innej drogi przedstawiciele ugrupowań zasiadających w rządzie lubelskim wybrać nie mogli. Po pierwsze, dlatego że wymuszał to sam skład gabinetu zdominowanego przez przedstawicieli szeroko rozumianej lewicy, czyli Polskiej Partii Socjalistycznej, Polskiej Partii Socjalno-Demokratycznej i Polskiego Stronnictwa Ludowego Wyzwolenie ${ }^{25}$. Po drugie zaś, szeroki program reform społeczno-politycznych wymuszała ówczesna trudna sytuacja polityczna na ziemiach polskich. Sam Daszyński o treści programowej w Manifeście pisał między innymi:

Pismo rządu lubelskiego zapowiada dalej bardzo daleko sięgające reformy społeczne w interesie ludu pracującego na wsi i w mieście, począwszy od ośmiogodzinnego dnia pracy aż do upaństwowienia przedsiębiorstw przemysłowych i górniczych, na wsi zaś przyrzeka wywłaszczenie wielkiej własności na rzecz małorolnych i bezrolnych wieśniaków. Skrajnie

23 Z. Zaremba, P.P.S. w Polsce niepodległej 1918-1932, [w:] Księga Jubileuszowa Polskiej Partii Socjalistycznej 1892-1932, red. A. Krieger et al., Warszawa 1933, s. 193.

24 Manifest Tymczasowego Rządu Ludowego Republiki Polskiej z dnia 7 listopada 1918 r. Lublin-Kraków.

${ }^{25}$ Lewicowy charakter rządu lubelskiego został nawet podkreślony w jego nazwie. 
demokratyczne żądania polityczne, uszanowanie prawa każdego narodu do decydowania o swym losie [...] — to wszystko razem czyniło z manifestu lubelskiego wspaniały program demokracji polskiej sięgającej po rządy w narodzie ${ }^{26}$.

Przedstawiony przez Daszyńskiego opis dokonań gabinetu lubelskiego — dokonań głównie co prawda w sferze ideowej, jak wiadomo bowiem, 11 listopada podał się on do dymisji — ewidentnie wskazuje, że socjaliści porzucili dążenia rewolucyjne na rzecz dominującej w ich działaniach koncepcji rozwoju polskiego parlamentaryzmu.

Sam Centralny Komitet Wykonawczy PPS od początku lat dwudziestych stał na stanowisku, iż wprowadzenie ustroju socjalistycznego powinno dokonać się w wyniku przejścia od demokracji do demokracji socjalnej. Ta ostatnia charakteryzować się miała uspołecznioną formą produkcji, dystrybucji i redystrybucji dóbr oraz parlamentarnym modelem sprawowania władzy. Generalizując, stwierdzić można, że po 1918 roku ugrupowanie stało na stanowisku opartym na przekonaniu, że zarówno doraźne, jak i główne cele socjalistów mogą być osiągnięte wyłącznie dzięki demokratyzacji państwa. Stanisław Michałowski pisał nawet, że w poglądach socjalistów w tym okresie dostrzec można:

nie tylko fascynację demokracją, ale wręcz swoiste posłannictwo zakładające obronę demokracji. To wówczas już zrodziło się wśród większości socjalistów przekonanie o wielkiej misji, jaką miała do spełnienia ich partia w procesie demokratyzacji państwa polskiego (oczywiście obok obrony niepodległości) i utrwalenia jego republikańskiego modelu ${ }^{27}$.

Za założeniami doktrynalnymi szła też odpowiednia taktyka wyborcza powodująca, że w kolejnych sejmach Związek Parlamentarny Polskich Socjalistów był siłą znaczącą.

Co ciekawe, niejednokrotnie założenia programowe ugrupowania korygowane były w wyniku aktualnych wydarzeń politycznych i konieczności stosowania doraźnej taktyki politycznej, na przykład już przed majem 1926 roku Polska Partia Socjalistyczna nie wahała się obsadzić dwóch tek ministerialnych w rządzie Aleksandra Skrzyńskiego, mimo że ich współkoalicjantem był prawicowy Związek Ludowo-Narodowy. Z doktrynalnego punktu widzenia nie tworzyło to jednak problemu, Centralny Komitet Wykonawczy Polskiej Partii Socjalistycznej postępowanie to tłumaczył, poniekąd słusznym, działaniem nakierowanym na rzecz ochrony interesów świata pracy. Założenia ideowe partii musiały zostać zweryfikowane w bieżącej sytuacji politycznej w kraju i zwykłym pragmatyzmem. Proces ten towarzyszył zresztą nie tylko polskim socjalistom, lecz także miał wymiar ogólnoeuropejski. Charakteryzowało go przekonanie ugrupowań o proweniencji socjalistycznej, że ustrój kapitalistyczny w Europie cechuje pewna stabilność i na-

26 I. Daszyński, Tymczasowy Rzad Ludowy Republiki Polskiej w Lubinie, [w:] P.P.S. Wspomnienia z lat 1918-1939, red. J. Czerski et al., Warszawa 1987, s. 206.

27 S. Michałowski, Myśl polityczna Polskiej Partii Socjalistycznej (1918-1939), Lublin 1994, s. 163. 
leży w związku z tym program demokratyczny realizować w obecnych warunkach. Za postępowaniem prowadzącym do realizacji celów socjalistycznych w drodze demokratycznej przemawiały zwłaszcza zdobycze socjalne uzyskane przez klasę robotniczą w okresie rządów Jędrzeja Moraczewskiego i Sejmu Ustawodawczego. $\mathrm{Na}$ realizację przez socjalistów postulatów partii, z jednoczesnym odstąpieniem od przekształceń rewolucyjnych, wskazywał między innymi Andrzej Ajnenkiel.

Socjaliści trzech zaborów, mimo istotnych niekiedy rozbieżności [...] stanęli na stanowisku wyrażonym w manifeście Tymczasowego Rządu Ludowego — realizacji reform społecznych przez demokratycznie wybraną konstytuantę. Partia pozostać miała wierna koncepcjom rozstrzygania problemów społecznych w drodze parlamentarnej — nawet wówczas, gdy groziło to odłożeniem realizacji jej postulatów na dalszą przyszłość 28 .

Nie oznacza to wszakże, że w PPS brakowało zwolenników drogi rewolucyjnej — byli obecni, lecz ich wpływ był znikomy. Jeszcze na początku lat dwudziestych grupa swoistych radykałów w partii, skupionych wokół Tadeusza Żarskiego i Adama Landego, lansowała hasła rewolucji socjalnej, obalenia rządów burżuazyjnych i proklamowania Polskiej Republiki Socjalistycznej. Najwyższym organem władzy proletariatu miał być kongres Rad Delegatów Robotniczych i Chłopskich. Zwolennicy radykalnej drogi do socjalizmu ponieśli jednak klęskę już w roku 1919. Przeciwko rozwiązaniom radykalnym opowiedział się zarówno XVI Zjazd, jak i XVI Kongres PPS, sam zaś Żarski przeszedł do Komunistycznej Partii Robotniczej Polski ${ }^{29}$.

O owej rozbieżności między socjalistami a komunistami pod względem ideowym i pragmatycznym pisał wspomniany już Kazimierz Więch, uwypuklając różnice w taktyce politycznej obydwu konkurencyjnych partii.

Socjaliści zmierzając do swego celu ostatecznego, jakim było zwycięstwo socjalizmu w Polsce, wybierali drogę dłuższą, ale w ich mniemaniu skuteczniejszą. Chcieli osiągnąc zamierzony cel poprzez wydzieranie klasom posiadającym częściowych ustępstw i tworzenie na zdobytym w ten sposób terenie w zalążkowej formie socjalistycznych struktur społecznych. Komuniści natomiast uważali, że warunkiem zapoczątkowania przemian o charakterze socjalistycznym jest zdobycie władzy politycznej drogą przewrotu rewolucyjnego ${ }^{30}$.

Na łamach organu prasowego partii, krakowskiego dziennika „Naprzód”, wskazywano między innymi, że metody stosowane przez organizacje socjalistyczne w dobie caratu nie przystają do realiów odrodzonego państwa.

Któż będzie śmiał powiedzieć, że w Polsce dzisiejszej są takie same warunki polityczne, jak za caratu? Któż będzie śmiał twierdzić, że drogą „puczów” i krwawych awantur i gwałtu

28 A. Ajnenkiel, Parlamentaryzm II Rzeczypospolitej, Warszawa 1975, s. 113.

${ }^{29}$ Grupa secesjonistów Tadeusza Żarskiego nie była jedyną, która z czasem przeszła na pozycje KPRP. Wskazać można również grupę zjednoczoną wokół byłego sekretarza generalnego i członka CKW Polskiej Partii Socjalistycznej — Jerzego Czeszejko-Sochackiego. Po krótkiej samodzielności pod politycznym szyldem Grupa członków PPS (Lewica) wstąpił do KPRP.

${ }^{30}$ K. Więch, op. cit., s. 219. 
dokona się zmiany ustroju społecznego? Nie wierzą w to sami komuniści, bo też ich celem nie jest walka $\mathrm{z}$ kapitałem, lecz walka z niepodległym państwem Polskim ${ }^{31}$.

W latach dwudziestych liderzy partii socjalistycznej wielokrotnie w swoich wypowiedziach i enuncjacjach prasowych wskazywali, że realizacja postulatów politycznych PPS powinna odbyć się pokojowo, z wykorzystaniem narzędzi politycznych typowych dla idei rządów parlamentarno-gabinetowych. Socjaliści z Niedziałkowskim na czele zwracali uwagę na istnienie owego „kryzysu parlamentaryzmu", o którym Niedziałkowski pisał w słynnej pracy Teoria i praktyka socjalizmu wobec nowych zagadnień. Naczelny ideolog ugrupowania Mieczysław Niedziałkowski wyraził tam pochwałę demokracji parlamentarnej, jakkolwiek dostrzegał jej wady. Ważkim sformułowaniem użytym przez wileńskiego działacza było jednoczesne poddanie krytyce i odrzucenie „dyktatury proletariatu” jako pośredniej formy ustrojowej między kapitalizmem a socjalizmem. „Widzieliśmy, że hasło [dyktatury proletariatu - przyp. W.K.] ongi ulubione wśród całej lewicy socjalistycznej, jest w istocie swojej nieziszczalne, należy do kategorii sorelowskich »mitów społecznych «"32. Fakt odrzucenia owej „dyktatury proletariatu” implikował z jednej strony odrzucenie szybkich i rewolucyjnych w swych metodach sposobów osiągnięcia ustroju socjalistycznego, z drugiej zaś konieczność poddania gruntownej reformie ustrojowej instytucji typowych dla demokracji parlamentarnej ${ }^{33}$.

Mimo to socjaliści w dwudziestoleciu uważali, że cele programowe ich ugrupowania, między innymi uspołecznienie gospodarki, ustawodawstwo socjalne, oddzielenie Kościoła od państwa czy też referendum ludowe, mogą być realizowane w sprawnie działającej demokracji parlamentarnej. Zacytować tu należy Mieczysława Niedziałkowskiego, który w przełomowym roku 1926 pisał właśnie, że demokracja parlamentarna:

Jest [...] formą najbardziej elastyczną, najbardziej subtelną. [...] Demokracja parlamentarna uzależnia politykę państwową w sprawach wielkich i małych od fluktuacji w opinii publicznej, w układzie stronnictw, wpływów liczebnych organizacji itp. Przyśpieszone niepomiernie, nerwowe, wytężone tętno życia współczesnego wymaga takiej właśnie konstrukcji ustrojowej; im subtelniej odbrzmiewa machina rządowo-parlamentarna na ton każdorazowy społeczeństwa, jego poszczególnych klas społecznych i grup politycznych, tym większe szanse pokojowego (sic!) na wewnątrz i na zewnątrz rozwoju państwa i narodu ${ }^{34}$.

31 Terroryści bolszewiccy, „Naprzód” 25 lipca 1925.

32 M. Niedziałkowski, Teoria i praktyka socjalizmu wobec nowych zagadnień, Warszawa 1926, s. 84.

33 Jednym z postulatów reformy ustrojowej w Rzeczypospolitej, proponowanej przez socjalistów skupionych w PPS, była likwidacja drugiej izby. Projektowano powołanie w miejsce senatu tak zwanej izby pracy - swoistej parlamentarnej reprezentacji środowisk robotniczych. Por. W. Kowalski, Koncepcje ustrojowe izby wyższej parlamentu w II Rzeczypospolitej, Warszawa 2014. Na ten temat też M. Śliwa, Instytucja Izby Pracy w programie społeczno-politycznym Polskiej Partii Socjalistycznej, „Studia Historyczne” 1980, nr 4.

34 M. Niedziałkowski, Mieczysław Niedziałkowski o demokracji i parlamentaryzmie, Warszawa 1996, s. 121-122. 
Tenże autor pisał dalej, iż odrzucić należy wizję wszelkich przewrotów:

wstrząśnienia społeczne czy polityczne posiadają duży urok, podobny do uroku opery wagnerowskiej. Ze stanowiska socjalistycznego wszakże przewrót rewolucyjny nie jest nigdy celem samym w sobie. Ceteris paribus „spokojny” typ ewolucji prawno-politycznej i społeczno-gospodarczej przedstawia daleko więcej stron dodatnich niż najpiękniejszy artystycznie wybuch gniewu ludowego ${ }^{35}$.

Akcentowano reformistyczne, ewolucyjne poglądy Mieczysława Niedziałkowskiego i wskazywano, że redaktor „Robotnika”

podkreślał potrzebę uświadamiania mas robotniczych o konieczności zaniechania żądań zmierzających do natychmiastowego przeprowadzenia głębokich reform ustroju społeczno-ekonomicznego. Kategorycznie sprzeciwiał się przy tym wszelkim wystąpieniom o charakterze rewolucyjnym ${ }^{36}$.

Feliks Perl, legendarny działacz i wieloletni redaktor naczelny PPS-owskiego „Robotnika”, również wyrażał przekonanie, że partia winna realizować swoje postulaty programowe, działając $\mathrm{w}$ ramach prawa.

Rewolucja — pisał Perl — rozumiana jako wielka przemiana społeczna, może się odbyć w różnych formach; w znacznym stopniu zależy to od czynników dzierżących władzę czy przyjdzie rewolucja z rozwianym włosem, z mieczem w dłoni, czy przyjdzie w majestacie prawa. My zasiadamy tutaj w Sejmie, my socjaliści, którzy agitowaliśmy za wyborami do tego Sejmu, którzy przyczyniliśmy się do powstania tego Sejmu, nadal w nim pracować chcemy i dołożymy wszelkich starań, ażeby rewolucja, która jest nieunikniona jako wielka przemiana społeczna, odbyła się u nas w całym majestacie prawa ${ }^{37}$.

Odnosząc się do tytułu artykułu, powiedzieć należy, że dla polskich socjalistów słynne hasło rewolucji w majestacie prawa oznaczało ni mniej, ni więcej tylko stopniową ewolucję ustroju, co w swej istocie było zaprzeczeniem rewolucji. Naczelni ideolodzy Polskiej Partii Socjalistycznej przeciwni byli rozlewowi krwi i niepokojom społecznym, o czym świadczyć mogą również słowa senatora i publicysty PPS Stanisława Posnera, który w wymownym artykule Jakim powinien być socjalista pisał następująco:

Trzeba ukochać wielki ideał odrodzenia ludzkości na zasadach równości, sprawiedliwości, braterstwa, do ideału tego kroczyć drogami prawdy i uczciwości, odrzucić precz demagogię i kłamstwo, ukochać człowieka, naród, ludzkość całą [...] a będziemy dobrymi socjalistami ${ }^{38}$.

35 Ibidem.

36 J. Gołębiowski, Gospodarcza rola państwa w programach i publicystyce Polskiej Partii Socjalistycznej 1918-1939, [w:] W stulecie polskiego ruchu robotniczego: studia i rozprawy, red. J. Gołębiowski, Kraków 1982, s. 88.

37 Wypowiedź Feliksa Perla podczas debaty w Sejmie Ustawodawczym nad wnioskiem Komisji Spraw Zagranicznych w sprawie sojuszu Rzeczypospolitej Polskiej z państwami sprzymierzonymi dla walki z Niemcami, Sprawozdanie Stenograficzne Sejmu Ustawodawczego z dnia 27 marca 1919 r., łam 1150, Warszawa.

38 S. Posner, Jakim powinien być socjalista?, [w:] Kalendarz robotniczy PPS na rok 1921, Warszawa 1921, s. 31; idem, W obronie demokracji. Przemówienie senatora Stanisława Posnera na posiedzeniu plenarnym Senatu w dniu 31 lipca 1926 roku, Warszawa 1926.

Studia nad Autorytaryzmem i Totalitaryzmem 41, nr 3, 2019

(C) for this edition by CNS 
W pierwszej połowie lat dwudziestych wyrazem swoistej, pełnej partycypacji Polskiej Partii Socjalistycznej w realiach państwa opartego na systemie parlamentarno-gabinetowym był aktywny udział członków ugrupowania nie tylko w działalności ustawodawczej, lecz także w formach aktywności społeczno-kulturalnej. Jan Tomicki tak pisał o tym procesie:

w warunkach istniejącego wówczas systemu demokratyczno-parlamentarnego socjaliści prowadzili aktywną działalność w różnego rodzaju instytucjach państwowych i społecznych oraz w organizacjach robotniczych, które tworzyli i rozwijali. [...] Pracę w służbie publicznej traktowano wtedy jako swego rodzaju powinność, powinność wobec własnej partii, wobec swego środowiska robotniczego i w ogóle wobec narodu. PPS popularyzowała takie wartości w postawach swych członków, które miały przejawiać się w pozytywnym stosunku do tradycji narodowych oraz instytucji demokratycznych państwa ${ }^{39}$.

Według takiego ujęcia nie może dziwić znaczny i nie do końca zresztą zbadany dorobek na polu edukacji utworzonego przez Ignacego Daszyńskiego Towarzystwa Uniwersytetu Robotniczego ${ }^{40}$.

PPS była kompozycją różnych środowisk, odmiennie ujmujących realizację programu, co z kolei generować musiało trudności w funkcjonowaniu ugrupowania. Emanacją problemów istniejących w partii, a dotyczących rzeczywistego źródła jej słabości, to znaczy wielości nurtów ujawniających się zarówno bezpośrednio w samej partii, jak i w środowiskach sympatyzujących z Polską Partią Socjalistyczną, było kształtowanie się lewicowego skrzydła w ugrupowaniu. Jedną z przyczyn tworzenia się wspomnianego nurtu był fakt, że poszczególne środowiska polityczne wniosły do PPS, jak wskazywał Ludwik Hass: „bagaż odmiennych koncepcji taktyczno-politycznych, różnych form organizacyjnych i swoistych metod działania oraz wewnątrzpartyjnych podziałów”⒈ Przypomnieć należy, że spory ideowo-polityczne w ugrupowaniu przed zamachem majowym, toczące się między umiarkowanym centrum partii — reprezentowanym między innymi przez Ignacego Daszyńskiego, Mieczysława Niedziałkowskiego, Feliksa Perla czy też Zygmunta Żuławskiego, a zwłaszcza jej lewym skrzydłem, dotyczyły zasadniczo kwestii uznania istniejącego państwa kapitalistycznego i upatrywania w jego strukturach, zwłaszcza w systemie demokracji parlamentarnej, szansy realizacji założeń programowych. To też nieustający spór dotyczący tak zwanej dyktatury proletariatu. W końcu powracające nieustannie pytanie o możliwość współuczestnictwa w rządach, na przykład obsadzenie tek ministerialnych w rządzie Aleksandra Skrzyńskiego i dylematy związane z obawą, że legitymacja tego gabinetu będzie ewentualną

39 J. Tomicki, Polska Partia Socjalistyczna 1892-1948, Warszawa 1983, s. 260-261.

$40 \mathrm{Na}$ ten temat między innymi A.M. Gajzler, Organizacja Młodzieży Towarzystwa Uniwersytetu Robotniczego (1923-1936). Model młodzieżowego ruchu kulturalno-oświatowego, Kraków 1993. Por. też Sprawozdanie z działalności Towarzystwa Uniwersytetu Robotniczego za rok 1927 i 1928, Warszawa 1929.

${ }^{41}$ L. Hass, Kształtowanie się lewicowego nurtu w Polskiej Partii Socjalistycznej na tle sytuacji wewnatrzpartyjnej (listopad 192-maj 1926), „Kwartalnik Historyczny” 1961, nr 1, s. 71. 
afirmacją rządów klas posiadających ${ }^{42}$. Jak wiadomo, obawa ta była jedną z wielu przyczyn odejścia z rządu Bronisława Ziemięckiego i Jędrzeja Moraczewskiego.

Wyrazem buntu części środowisk lewicowych skupionych w PPS wobec oficjalnej linii partii i uczestnictwa w rządzie była aktywizacja i radykalizacja postaw lewego skrzydła partii i tworzenie się nowych ugrupowań lewicowych z lokalnych struktur PPS. Przykładem może być działalność Zygmunta Zaremby czy też powstanie w Lublinie Niezależnej Partii Chłopskiej. Rekapitulując, działalność lewego skrzydła ugrupowania, jakkolwiek potencjalnie niebezpieczna dla głównego nurtu partii, akcentująca przed 1926 roku konieczność radykalizacji postaw i domagająca się weryfikacji faktycznych osiągnięć lewicy uzyskanych w warunkach demokratycznego państwa, nie odegrała poważniejszej roli. Rewolucjonizm i radykalizm poglądów członków lewicy PPS zastępował bądź reformizm, bądź perspektywa przejścia na stanowiska bliskie ideowo ruchowi komunistycznemu.

W celu komplementarności toczonych rozważań wspomnieć należy również o koncepcjach syndykalistycznych w dwudziestoleciu, zakładających odejście od ideałów demokracji parlamentarnej na rzecz tak zwanej demokracji nieliberalnej, odgrywających pewną rolę w tworzeniu alternatywy wobec ówczesnego paradygmatu demokracji, odnośnie do których PPS musiała zająć stanowisko. Przypomnieć należy, że w ówczesnym rozumieniu demokracji przez CKW PPS ta jawić się miała jako poszanowanie struktur władzy opartej na wolnych wyborach, legitymowanych wolą wyborców, przyznaniem kluczowej roli w strukturze podziału władzy parlamentowi i docenieniem roli samorządu. Tak postrzegana demokracja tworzyć miała podstawę do przeprowadzenia postulowanej rewolucji socjalnej. Główni ówcześni syndykaliści, z Jerzym Szurigiem i Kazimierzem Zakrzewskim na czele, przeprowadzenie zamachu majowego, podobnie zresztą jak początkowo uczynili to liderzy Polskiej Partii Socjalistycznej, traktowali jako szansę realizacji postulatów ruchu syndykalistycznego. Traktowanie wszak syndykalistów jako epigonów PPS odnośnie do próby politycznego zagospodarowania środowisk robotniczych byłoby nieprawdziwe. Nie wdając się w szczegółową analizę ruchu ,zetowego" i ówczesnych struktur syndykalistów, podkreślić wszakże wypada, że jednym z celów polskiego ruchu syndykalistycznego było utworzenie syndykalistycznych związków zawodowych skupionych w ramach Generalnej Federacji Pracy.

Impulsem, który spowodował uaktywnienie się grupy skupionej wokół Szuriga i Zakrzewskiego, stał się przewrót majowy. Syndykaliści, podobnie jak ogół zwolenników Piłsudskiego, powitali zamach majowy z ogromnymi nadziejami, ich ocena sytuacji wyróżniała się jednak zasadniczo na tle prezentowanych wówczas opinii. Dla Szuriga, Zakrzewskiego [...] triumf „Rewolucji Majowej” był oczywistym dowodem bankructwa modelu liberalno-demokratycznego, ostatecznym końcem zdegenerowanego „państwa partyjnego” i czytelnym sygnałem, że kapitalizm w Polsce dożywa swoich $\mathrm{dni}^{43}$.

42 Podobna sytuacja uwidoczniła się również w udzieleniu poparcia przez PPS rządowi Grabskiego.

43 G. Zackiewicz, Z dziejów syndykalizmu polskiego: geneza i działalność Generalnej Federacji Pracy (1928-1931), „Dzieje Najnowsze” 2009, z. 1, s. 28. Por. też idem, Syndykaliści w obozie 
Nie dziwi, że inicjatywa syndykalistów została odebrana przez CKW PPS jako poważne zagrożenie, czemu dał wyraz wprost w imieniu władz partii M. Niedziałkowski, pisząc na łamach „Robotnika”, iż „syndykaliści spod chorągwi sanacyjnej — to albo pozostałość z okresu przedwojennego, albo sztuczne robione $» k$ liki«, dalekie od rzeczywistych potrzeb i dążeń mas"44.

Przełom lat dwudziestych i trzydziestych niósł dla doktrynerów PPS również inne wyzwania. Zaistniała konieczność odniesienia się do coraz popularniejszych po 1926 roku w obozie sanacyjnym koncepcji etatystycznych. Jak wspomniano, w programie lewicy z 1920 roku kwestia uspołecznienia gospodarki przeciwstawiana była omnipotencji gospodarczej trustów, karteli i banków ${ }^{45}$. Poglądy przyjęte wówczas przez liderów ugrupowania zdaniem Jerzego Gołębiowskiego stały się swoistym paradygmatem postrzegania przyszłych przeobrażeń istniejącego w państwie modelu gospodarczego: „Obowiązujący od 1920 r. program PPS spowodował spadek zainteresowania tej partii przeobrażeniami struktury własnościowej w Polsce. Socjaliści skupili swoją uwagę na wysuwaniu doraźnych żądań ekonomicznych i reform społecznych" ${ }^{46}$. Przypomnieć należy także, że Niedziałkowski w połowie lat dwudziestych wyraźnie przestrzegał przed dokonywaniem pochopnych prób przebudowy struktury własnościowej ${ }^{47}$. Liczono, że udzielając Piłsudskiemu poparcia w 1926 roku, uda się przeprowadzić część z zamierzonych reform. Stosunek rządu do lewicy parlamentarnej szybko zweryfikował te nadzieje. PPS, przechodząc do opozycji, krytykowała więc siłą rzeczy etatystyczne koncepcje sanatorów odnośnie do kierowania gospodarką. Podkreślić wypada, że koncepcje etatystyczne budziły żywe spory także w obrębie obozu pomajowego. Wyrazem sprzeciwu wobec koncepcji etatystycznych w gospodarce był artykuł redaktora „Robotniczego Przeglądu Gospodarczego” Antoniego Zdanowskiego, w którym podkreślał on, że polityka gospodarcza rządów sanacyjnych jest je-

„,rewolucji majowej” (1926-1935), „Studia Podlaskie” 16, 2006, s. 70. Także na ten temat R. Chwedoruk, Ruchy i myśl polityczna syndykalizmu w Polsce, Warszawa 2011.

${ }^{44}$ M. Niedziałkowski, Wczoraj i jutro, „Robotnik” 1 stycznia 1929, s. 1. Nadmienić trzeba, że zdaniem G. Zackiewicza Generalna Federacja Pracy nie była tworem proweniencji sanacyjnej. Krytykę obozu syndykalistycznego przeprowadził w ślad za Niedziałkowskim J. Stańczyk, pisząc o „,zbankrutowanym syndykalizmie bezpartyjnym” oraz podkreślając nierozerwalność walki politycznej z celami ruchu zawodowego. Zob. idem, Wplyw politycznej organizacji klasy robotniczej na akcje zawodowe „Robotnik” 9 stycznia 1929, s. 1. O nurcie syndykalistycznym w II Rzeczypospolitej więcej G. Zackiewicz, Syndykalizm w polskiej refleksji i rzeczywistości politycznej I potowy XX wieku, Kraków 2013.

45 W zakresie stosunków gospodarczych, w Programie PPS postulowano między innymi: „Uspołecznienie dojrzałych do tego gałęzi przemysłu, przede wszystkim kopalń i wszelkiego rodzaju, hut i środków komunikacji. Uspołecznienie w formie własności gminnej przedsiębiorstw, służących do zaspokajania potrzeb ogółu mieszkańców gminy, jak np. elektrowni, gazowni, tramwajów, aptek, piekarń, jatek, domów mieszkalnych”. Por. Program Polskiej Partii Socjalistycznej uchwalony na XVII Kongresie w Warszawie w dniach 21-25 maja 1920, Warszawa 1920.

46 J. Gołębiowski, op. cit., s. 86.

47 Zob. M. Niedziałkowski, Teoria i praktyka socjalizmu wobec nowych zagadnień, Warszawa-Kraków 1926. 
dynie quasi-etatyzmem. O prawdziwym kierowaniu gospodarką przez państwo w konsekwentnej planowej polityce gospodarczej nie może być mowy, albowiem „o kierunku polityki gospodarczej decyduje Lewiatan przemysłowy”48. Rozważania Zdanowskiego kończyła konstatacja, że zagadnienie prawdziwego etatyzmu podniesione może zostać jedynie przez zorganizowaną klasę robotniczą ${ }^{49}$.

Krytykę koncepcji etatystycznych piętnował na łamach „Robotnika” wieloletni redaktor pisma Jan Maurycy Borski. Podkreślał on, że liberalizm gospodarczy w ówczesnych uwarunkowaniach międzynarodowych był zaledwie utopią, z czego z kolei wynikała konieczność przeciwstawienia się burżuazji. W poglądach Borskiego, lokujących go w centrum PPS, dostrzec można argumenty paralelne do przekonań Antoniego Zdanowskiego. Publicysta „Robotnika” wypowiadał się $\mathrm{z}$ nieufnością co do realnych możliwości funkcjonowania w Polsce gospodarki kontrolowanej przez państwo, w sposób realnie niezależny od klas posiadających: „musimy bacznie śledzić, czy każde etatystyczne posunięcie rządu, korzystne dla klas posiadających, nie kryje w sobie niebezpieczeństwa dla mas pracujących"50. Atak na efektywność etatyzmu gospodarczego w kontekście ustanowienia gospodarki planowej przeprowadził też Zygmunt Zaremba: „Wszelkie etatyzmy czy interwencjonizmy są tylko narzędziami w ręku określonych grup kapitalistycznych dążących do monopolu [...]. W tych warunkach każdy interwencjonista czy etatysta staje się w praktyce sługą kapitalistów [...]”51. Gwaranta urzeczywistnienia przebudowy życia gospodarczego w państwie Zaremba upatrywał w istnieniu rządu złożonego z robotników i włościan, ten zaś prowadzić miał społeczną gospodarkę planową.

Konkludując, wskazać należy, że PPS w okresie dwudziestolecia to ugrupowanie o charakterze ewolucyjnym, nie zaś rewolucyjnym, samo natomiast poparcie zamachu majowego było krótkotrwałe. Partia, pomijając pewne frakcje i zawirowania polityczne, była ugrupowaniem akcentującym w swoim programie demo-

48 A. Zdanowski, Etatyzm, „Robotniczy Przegląd Gospodarczy” 1929, nr 2, s. 33.

49 W debacie toczącej się podczas obrad IV Kongresu Delegatów Związków Zawodowych w Warszawie w dniach od 30 maja do 2 czerwca 1929 roku A. Zdanowski uwypuklał problem braku społecznej kontroli nad największymi przedsiębiorstwami. Opowiadał się między innymi za utworzeniem państwowej rady gospodarczej będącej reprezentacją środowisk robotniczych. Zob. Wnioski na IV Kongres Delegatów Związków w Warszawie, „Robotniczy Przegląd Gospodarczy” 12 maja 1935, dodatek s. 3.

50 J.M. Borski, Ich etatyzm, „Robotnik” 31 sierpnia 1929, s. 1; idem, Etatyzm, „Robotnik” 27 stycznia 1929, s. 1. Adam Urbanowicz podkreśla: „Nie przeszkadzało to socjalistom sprzeciwiać się stanowczo wszelkim próbom prywatyzacji przedsiębiorstw należących do państwa”, idem, Uspołecznienie własności i wizja nowego ładu gospodarczego w polskiej myśli socjalistycznej (1918-1939), Gorzów Wielkopolski 2013, s. 186.

51 Z. Zaremba, Bezdroża kapitalizmu i drogowskazy przyszłości, Warszawa 1933, s. 126127. Kazimierz Dziewulski, odnosząc się do stosunku socjalistów wobec zagadnienia etatyzmu, podkreślał: „W centrum uwagi PPS znajdowało się uspołecznienie środków produkcji; w opinii członków partii etatyzm nie oznaczał takiego uspołecznienia”, idem, Spór o etatyzm 1919-1939, Warszawa 1981, s. 120. 
kratyzm, republikańską formę rządów, konieczność długotrwałych przemian społecznych i przywiązanie do rządów parlamentarnych — jakkolwiek jeszcze nie doskonałych, na co wskazywali liderzy partii. Wypowiadała się, jak pisał Michał Śliwa: ,za oparciem ustroju odrodzonego państwa na zasadach demokracji politycznej i społecznej"52. Autorytarne prądy w obrębie PPS dotyczyły tylko pewnych i czasem wpływowych frakcji oraz miały charakter efemeryczny, a ich nasilenie trwało do końca lipca 1926 roku. Wówczas to pojawił się wyraźny rozdźwięk między przywódcami Polskiej Partii Socjalistycznej (zwłaszcza CKW partii) a środowiskiem piłsudczykowskim odnośnie do celów politycznych i form ich realizacji ${ }^{53}$. Wraz z obaleniem rządu Witosa socjaliści liczyli na rozwiązanie Sejmu i rozpisanie nowych wyborów, podczas gdy rząd z Kazimierzem Bartlem na czele dążył do poszerzenia uprawnień władzy wykonawczej kosztem parlamentu. Sprzeciw PPS wobec zamierzeń zwycięzcy majowego przesilenia w kwestii zmian w konstytucji wyraźnie zakomunikował stronnictwu piłsudczyków Stanisław Posner, wskazując z mównicy senackiej, że dla Polskiej Partii Socjalistycznej zmiany ustrojowe nie mogą się opierać na deprecjacji demokracji i znaczenia władzy ustawodawczej.

dziś jest pewnego rodzaju psychoza na świecie, w kierunku wymiatania Sejmu i Senatu. [...] Teraz przyszła moda na świecie taka, że cokolwiek jest złego i gdziekolwiek coś złego się stało, to wszystko składa się na karb istnienia w tym nowym [...] świecie [...] mianowicie na tę starą instytucję [...] która nazywa się parlamentem ${ }^{54}$.

Istotne jest odwołanie się przez lewicowego senatora Stanisława Posnera do monteskiuszowskiej koncepcji trójpodziału władzy, rozumianej jako gwarant stabilności państwa. „Bez podziału władz — mówił S. Posner — nie może być żad-

52 M. Śliwa, Polska myśl socjalistyczna (1918-1948), Wrocław 1988, s. 39. Zagadnienie to akcentował Roman Bäcker: „Akceptacja demokracji parlamentarnej była rezultatem przekonania, iż ta forma ustrojowa nie tylko jest najprostszą i najmniej uciążliwą dla kraju drogą do socjalizmu, ale i pozwala na prawie natychmiastowe uzyskanie przez robotników możliwie największej porcji praw i wolności”, idem, Problematyka państwa w polskiej myśli socjalistycznej lat 1918-1948, Toruń 1994, s. 84. Z tego przekonania liderów PPS wynikała również konieczność prowadzenia wśród członków proletariatu zintensyfikowanej działalności o charakterze edukacyjnym.

53 Swoiste zauroczenie części liderów lewicy sejmowej Piłsudskim było krótkotrwałe. $\mathrm{O}$ znacznych złudzeniach niektórych przedstawicieli władz naczelnych PPS i Centralnego Komitetu Wykonawczego co do zamiarów i przyszłej polityki Piłsudskiego wypowiedział się między innymi Hermann Liebermann: „Pozornie nie miałby Piłsudski większości w Sejmie, lecz lewica byłaby poruszyła kraj i opinię publiczną, a Sejm byłby się ugiął wobec potężnego ruchu ludowego, który i bez umyślnej agitacji byłby powitał go jako odnowiciela życia publicznego po niefortunnych i w znacznej mierze nieudolnych rządach prawicowo-centrowych. Zresztą w opinii publicznej silnie zakorzenione były w owym czasie złudzenia co do osoby Piłsudskiego, co do jego demokratyzmu i radykalizmu w sprawach społecznych", idem, Przewrót majowy 1926 r., [w:] P.P.S. Wspomnienia z lat 1918-1939, s. 592. Przypomnieć należy, że Liebermann należał do najbardziej nieprzejednanych przeciwników Piłsudskiego w partii, co jak wiadomo, miało kluczowy wpływ na jego losy po 1926 roku.

54 Sprawozdanie stenograficzne z 136 posiedzenia Senatu w dniu 31 lipca 1926 r., łam 14, Warszawa 1926. 
nego nowoczesnego na prawie opartego państwa. Na prawie, a nie na sile, na tym prawie, które jest siłą, na sile, która jest prawem. Nie ma innego podziału"55. Jak wskazywał, rozejście się Polskiej Partii Socjalistycznej z obozem marszałka Józefa Piłsudskiego polegało na niemożności połączenia haseł socjalistów z autorytarną drogą walki z parlamentem, lansowaną przez świeżo powstałą tak zwaną sanację.

Z czasem jednak entuzjazm wywołany walką z centroprawicowym rządem oraz hasłami uzdrowienia życia publicznego zaczął zanikać i jasnym powoli stawało się, jak złudne były nadzieje żywione przez socjalistów. Dążenie do wzmocnienia władzy wykonawczej, przy jednoczesnym wyraźnym lekceważeniu przez nowy rząd postulatów zgłaszanych przez przywódców PPS, sprzyjało zmianie poglądów ${ }^{56}$.

Zastanawiać się można jedynie, czy owo dość szybkie rozejście się socjalistów z szeroko rozumianym środowiskiem piłsudczyków nie nastąpiłoby dużo wcześniej, gdyby Piłsudski miał skrystalizowany program polityczny zamiast dość lakonicznych hase ${ }^{57}$. Znany publicysta i działacz PPS Stanisław Dubois tak pisał o braku jakichkolwiek enuncjacji ze strony Rady Ministrów co do zamierzeń rządu:

Niestety, o celach rządu nic powiedzieć nie możemy na zasadzie słów czy enuncjacji jego kierowników. Zachowują oni grobowe milczenie, osłaniając się jakąś zasłoną tajemniczości, która w państwie demokratycznym jest nie do pomyślenia. Społeczeństwo ma wszak prawo wiedzieć, co rząd odpowiedzialny czynić zamierza ${ }^{58}$.

Dodać należy, że pozostające w obrębie PPS frakcje piłsudczykowskie, z Rajmundem Jaworowskim na czele, popierające formułę rządów autorytarnych nie odegrały znaczniejszej roli w partii i ostatecznie w 1928 roku opuściły jej szeregi, tworząc nowe ugrupowanie konkurujące o wpływy wśród elektoratu - Polską Partię Socjalistyczną dawną Frakcję Rewolucyjną ${ }^{59}$. Paradoksalnie, na co wskazuje Jarosław Tomasiewicz,

ideologia Frakcji Rewolucyjnej miała, wbrew nazwie, charakter na wskroś ewolucyjny. Zdaniem teoretyków partii rozwój współczesnej gospodarki w sposób nieuchronny prowadzi do

55 Ibidem, łam 17.

56 K. Piskała, Ku Rzeczypospolitej Socjalistycznej. Studium z dziejów myśli socjalistycznej PPS (1929-1939), Łódź 2017, s. 206.

57 Nadmienić można, że lakoniczność haseł i brak skonkretyzowanego programu politycznego piłsudczyków przekładały się poniekąd na uniwersalizm wystąpienia Józefa Piłsudskiego. Umożliwiało to poszukiwanie i pozyskiwanie zwolenników wśród działaczy większości ówczesnych ugrupowań politycznych. Łączyć miała osoba marszałka, nie zaś hasła programowe.

58 S. Dubois, Wobec sytuacji pomajowej, [w:] idem, Wybór artykułów i przemówień, Warszawa 1988, s. 101.

59 Więcej o Polskiej Partii Socjalistycznej dawnej Frakcji Rewolucyjnej pisał Bogdan Głowacki, Polityka Polskiej Partii Socjalistycznej 1929-1939, Warszawa 1979, s. 30 n. Nadmienić należy, że wśród czynników różnicujących PPSdFR od właściwego PPS-u, oprócz programu politycznego, a zwłaszcza stosunku do sanacji, było uciekanie się przez rozłamowców do metod wprost terrorystycznych. PPSdFR dążyła do rozbicia zarówno struktur PPS na Mazowszu - co częściowo zakończyło się powodzeniem, jak i w kraju, co się grupie tak zwanych jaworowszczyków nie udało. 
„socjalizmu państwowego”, w którym państwo nie tylko angażuje się bezpośrednio w gospodarkę, ale kontroluje też sektor prywatny ${ }^{60}$.

W poglądach PPSdFR na pierwszy plan wysuwał się wszakże postulat niepodległości, nie zaś kwestie wspominanego etatyzmu. Władze ugrupowania z Jędrzejem Moraczewskim, Medardem Downarowiczem i Romualdem Jaworowskim na czele podkreślały gotowość do współuczestnictwa w rządzie, traktowanego przez liderów ugrupowania jako szansa na reprezentację interesów robotników: „my chcemy [pisano na łamach organu ugrupowania „Przedświtu”], aby polski świat robotniczy uczestniczył w rządach państwem i mnożył siły tego państwa, a oni chcą [PPS - przyp. W.K.] — zasadniczej opozycji dopóty, dopóki socjaliści nie będą mogli sami [...]"61. Liderów PPSdFR z piłsudczykami łączyło też przekonanie o ułomności parlamentaryzmu. Zdaniem J. Tomasiewicza poglądy Frakcji Rewolucyjnej, programowo przeciwne syndykalizmowi, cechowało przyznanie pierwszeństwa w systemie ustrojowym zasadom demokracji bezpośredniej: wyborom powszechnym głowy państwa, instytucji referendum, idei samorządności ${ }^{62}$.

Partia o strukturach tak rozbudowanych jak PPS w okresie dwudziestolecia była ugrupowaniem wewnętrznie niejednorodnym, wręcz bardzo zatomizowanym pod względem podziału na pomniejsze frakcje. Spowodowało to, że w latach 1927-1929, a więc w okresie stopniowego przechodzenia Polskiej Partii Socjalistycznej na pozycje opozycyjne wobec polityki marszałka Józefa Piłsudskiego i jego zaplecza politycznego część działaczy lewicy stanęła przed swoistym dylematem. Jego istotą była konieczność opowiedzenia się przez członków PPS za lub przeciw formule rządów autorytarnych sprawowanych przez Józefa Piłsudskiego. Jakkolwiek zdecydowana większość członków ugrupowania przeszła do opozycji wobec obozu pomajowego, to odnotować można tendencję wśród znanych działaczy Polskiej Partii Socjalistycznej, którzy nad ponadpartyjną jedność przedłożyli sympatię dla osoby komendanta. Poza swoistym partyjnym nieposłuszeństwem Jędrzeja Moraczewskiego przykładem takiej postawy może być słynny i emocjonalny w swej treści list wieloletniego działacza i posła PPS w Krakowie dr. Emila Bobrowskiego do okręgowego komitetu robotniczego. W liście tym późniejszy wieloletni senator z listy Bezpartyjnego Bloku Współpracy z Rządem Józefa Piłsudskiego pisał między innymi: „Nie stanę do walki przeciwko bojownikom Niepodległości, przeciw Józefowi Piłsudskiemu, którego całe życie jest ofiarną walką o wyzwolenie narodowe i społeczne, którego zasługi dla Państwa i klasy robotniczej są bezsporne" ${ }^{63}$. Stanisław Michałowski podkreśla, że po wyborach parla-

60 J. Tomasiewicz, Naprawa czy zniszczenie demokracji? Tendencje autorytarne i profaszystowskie w polskiej myśli politycznej 1921-1935, Katowice 2012, s. 336.

61 Uczestnictwo socjalizmu w rządach państwem, „Przedświt. Dziennik socjalistyczny” 14 listopada 1928, s. 1.

62 J. Tomasiewicz, op. cit., s. 337.

${ }^{63}$ E. Bobrowski, Wystapienie dr Emila Bobrowskiego z P.P.S. C.K.W., Kraków 1929, druk ulotny, s. 2 . 
mentarnych 1928 roku wciąż „przywódcy PPS bronili z jednej strony demokracji i sejmu, a z drugiej żywili nadzieję, że ze strony Piłsudskiego i BBWR nastąpi swoiste opamiętanie [...]"64. Jak wiadomo, ostatecznym i brutalnym kresem tych mrzonek były wybory odbywające się w cieniu Brześcia.

Wyrazem niełatwych wyborów wielu działaczy PPS postawionych wobec konieczności rozstrzygnięcia dylematu: Piłsudski czy partia, było przyjmowanie przez niektórych członków partii poglądów ambiwalentnych. Próbowali pogodzić akceptację zasług dla niepodległości państwa Józefa Piłsudskiego oraz znaczenia przewrotu majowego z posłuszeństwem względem dyscypliny partyjnej, co niejednokrotnie się nie udawało. Przykładem takiej postawy wśród członków partii może być wystąpienie działaczki socjalistycznej, posłanki na Sejm w latach 1922 i 1928, Zofii Praussowej. Podczas obrad XXI Kongresu PPS w listopadzie 1928 roku mówiła wprost zebranym:

\begin{abstract}
Wypadki majowe były koniecznością dziejową! Sejm był niezdolny do utrzymania władzy (wrzawa). Partia nie była wtedy gotowa do objęcia władzy (wielka wrzawa). Piłsudski zrobił to, co powinien był zrobić. Niepodległość Polski jest i celem sama w sobie, i środkiem. Na księżycu nie możemy socjalizmu budować. [...] Odcięliście front prawy. Socjalizm nie może składać się z jednego frontu. [...] Wolno mi w PPS mieć szacunek do Piłsudskiego. To nikomu nie przeszkadza. Nie wolno z partii robić więzienia ideowego. (wielka wrzawa) [...] Do secesji Jaworowskiego nie przystąpiłam. Powiedziałam dawno, że po żadnej stronie w razie rozłamu nie stanę. Nie było w mej mocy powstrzymać rozłamu. W sejmie głosowałam od dłuższego czasu wbrew swemu sumieniu. Dziś składam mandat poselski, bo nie mogę ideologicznie reprezentować Kongresu ${ }^{65}$.
\end{abstract}

Nawet gdy przyjmie się, że działalność Zofii Praussowej wpisywała się w aktywność piłsudczykowskiej grupy w CKW, nie umniejsza to faktu nakładania się na siebie kwestii osobistych — na przykład działalność Zofii Praussowej w Organizacji Bojowej PPS i znajomość z Piłsudskim, z obowiązkami partyjnymi ${ }^{66}$. Takich postaw było wiele. Jak wiadomo, Zofia Praussowa ostatecznie opuściła szeregi PPS i współtworzyła PPS Frakcję Rewolucyjną, mandatu poselskiego zaś nie złożyła.

Wyznacznikiem tych zawiłych podziałów niegdysiejszych towarzyszy partyjnych był stosunek do państwa sanacyjnego po 1926 roku. Jakkolwiek liderzy PPS po odejściu z ugrupowania tak zwanej prawicy piłsudczykowskiej podzielali pogląd o konieczności podjęcia działań opozycyjnych, to już sami poważnie się różnili co do faktycznego charakteru tej opozycji. Explicite wskazuje na to powołanie przez Radę Naczelną PPS „Komitetu pięciu”, z Mieczysławem Niedziałkowskim, Norbertem Barlickim i Hermanem Liebermanem na czele. O ile Niedziałkowski

${ }^{64}$ S. Michałowski, Polscy socjaliści, [w:] Więcej niż niepodległość. Polska myśl polityczna 1918-1939, red. J. Jachymek, W. Paruch, Lublin 2001, s. 306.

65 Sprawozdanie z XXI Kongresu PPS. Dąbrowa Górnicza-Sosnowiec, (1-go, 2-go, 3-go i 4-go listopada 1928 roku), Warszawa 1928, s. 60-61.

${ }^{66}$ Michał Śliwa podkreśla, że sterowane zakulisowo przez piłsudczyków secesje i rozłamy dotknęły niemal wszystkich ugrupowań obecnych na ówczesnej scenie politycznej. Por. idem, Polska myśl polityczna w I połowie XX wieku, Wrocław 1993, s. 98-99. 
był za stopniowaniem wystąpień opozycyjnych, Barlicki, jak wskazywał J. Tomicki, ,zalecał środki bardziej radykalne"67.

Wydarzenia maja 1926 roku spowodowały swoistą reorganizację środowisk tworzących Polską Partię Socjalistyczną. Zamach majowy dla pewnych nurtów reprezentowanych w ugrupowaniu stał się impulsem do swoistej reorientacji czy też przewartościowania poglądów dotyczących metod i sposobów osiągania celów ugrupowania - w tym aprobaty stosowania środków radykalnych. Znaczna wszakże część środowisk polskich socjalistów trwała na stanowisku wyrażającym pogląd o konieczności dalszego rozwoju koncepcji rządów parlamentu, choć niektórzy z liderów PPS dopuszczali możliwość dokonania w dotychczas funkcjonującym systemie demokracji parlamentarnej pewnych korekt. Explicite wyrażał takie poglądy Mieczysław Niedziałkowski, wskazując w roku 1926 na, z jednej strony, konieczność utrzymania demokracji parlamentarnej jako systemu uniwersalnego. „Próby zastąpienia demokracji parlamentarnej innymi ustrojami prawnopaństwowymi nie dadzą [...] rezultatu. Forma prawnopaństwowa dzisiejszego społeczeństwa musi być elastyczną, jak najmniej krępującą przebieg walk społecznych [...]"68. Z drugiej zaś, redaktor naczelny „Robotnika” dopominał się o upowszechnienie instytucji referendum, likwidację drugiej izby czy też usprawnienie rozwiązywania parlamentu przed końcem kadencji. Na wymienione poglądy nałożyć należy fakt, że tragiczne wydarzenia maja 1926 roku uaktywniły i dały asumpt do aktywnego działania licznym adherentom środowisk krytycznych względem zasad demokracji liberalnej.

Autorytarne fascynacje niektórych środowisk tworzących PPS nie ograniczały się jedynie do wspomnianych frakcji skupionych wokół komunistów: Tadeusza Żarskiego czy Jerzego Czeszejko-Sochackiego, czy też środowisk bliskich Piłsudskiemu. Swoistym probierzem poglądów panujących w obrębie ugrupowania po 1926 roku, zwłaszcza zaś w latach trzydziestych, była kwestia tak zwanej dyktatury proletariatu. Jak wiadomo, już w 1919 roku Mieczysław Niedziałkowski, pracując nad projektem programu PPS, nie zdecydował się na umieszczenie w nim sformułowania o tak zwanej dyktaturze proletariatu. Rozważania toczące się do połowy lat trzydziestych w partii koncentrowały się nie tyle na kształcie przyszłej dyktatury proletariatu, ile w ogóle na realnych szansach realizacji ideałów socjalistycznych w warunkach demokracji parlamentarnej. Michał Śliwa wskazuje, że „Działacze PPS przyznawali, że w sytuacji politycznej lat trzydziestych odżyło zainteresowanie zagadnieniem dyktatury proletariatu, a hasło to stało się atrakcyjne dla części socjalistów” ${ }^{69}$. Podkreśla jednocześnie, że centrum ugrupowa-

67 J. Tomicki, Norbert Barlicki, Warszawa 1968, s. 227.

68 M. Niedziałkowski, Teoria i praktyka socjalizmu wobec nowych zagadnień, s. 18. Zagadnienie to omawia szerzej Michał Śliwa. Zob. Uwagi Mieczysława Niedziałkowskiego o tzw. kryzysie parlamentaryzmu, „Dzieje Najnowsze” 1979, z. 1, s. 53 n.

69 M. Śliwa, Dyktatura proletariatu w publicystyce i programach Polskiej Partii Socjalistycznej, s. 86. 
nia z Mieczysławem Niedziałkowskim na czele dzieliło przekonanie, że „dyktatura klasy społecznej pod względem technicznym jest niewykonalna"70. Krytyka takich przekonań płynęła zarówno z lewego skrzydła ugrupowania, na przykład poglądy Bolesława Drobnera, jak i sympatyzującego przez pewien czas z Komunistyczną Partią Polski działacza socjalistycznego Wiktora Altera. Ten ostatni zresztą wprost podkreślał, że w tak zwanym okresie przejściowym rząd socjalistyczny w dziedzinie gospodarczej winien dążyć do likwidacji potęgi gospodarczej kapitalistów, wszakże bez urzeczywistniania integralnego socjalizmu. Alter przytaczał negatywne doświadczenia Związku Radzieckiego w kontekście walki z drobnomieszczaństwem. Wskazywał wprost, że:

Likwidacja potęgi gospodarczej kapitalistów jest dla rządu socjalistycznego koniecznością zarówno polityczną, jak i gospodarczą. Polityczną — gdyż tylko w ten sposób można zapobiec odradzaniu się hydry kontrrewolucji. Gospodarczą — gdyż tylko pod tym warunkiem można uniknąć sabotażu kapitalistów i przystąpić do realizacji gospodarki planowej ${ }^{71}$.

Cele te miały zostać osiągnięte przez z jednej strony uspołecznienie dużych przedsiębiorstw, z drugiej zaś „ograniczenie majątku i dochodów jednostki pewnym maksimum (sic!)”. Na temat dyktatury proletariatu wypowiadał się na początku lat trzydziestych również Jan Maurycy Borski, wskazując, że: „,nie jest ona zagadnieniem programu socjalistycznego, nie wchodzi w zakres celów socjalistycznych. W walce o socjalizm dyktatura jest jednym z licznych narzędzi, którymi proletariat się posługuje, jednym ze środków taktycznych"72. Borski podkreślał jednocześnie, że wspomniana tak zwana dyktatura proletariatu zaistnieć ma na skutek rewolucji politycznej, nie zaś społecznej.

Wyrazem przeciwstawienia się przez kierownictwo ugrupowania koncepcjom lewicy socjalistycznej było pominięcie tego hasła w treści programu PPS przyjętego przez XXIV Kongres w Radomiu 2 lutego 1937 roku. Warto wskazać, że w programie nie pojawia się ani razu określenie „dyktatura proletariatu”, Centralny Komitet Wykonawczy stosował określenie "mas pracujących miast i wsi"73. Odejście od pojęcia „dyktatura proletariatu” tłumaczyć należy wyraźnym wskazaniem, że ruch socjalistyczny nie jest ograniczony już wyłącznie do bazy proletariackiej. W programie podkreślono znaczenie włościaństwa, inteligencji pracującej, młodzieży czy też bezrobotnych. Akcentowano jednocześnie, że walka o realizację celów socjalistów oraz wyrwanie się spod dogmatu gospodarki kapi-

70 Ibidem. M. Śliwa przytacza tu zwłaszcza artykuł M. Niedziałkowskiego Prawo rozwojowe dyktatury, ,Robotnik” 10 czerwca 1933.

71 W. Alter, Gdy socjaliści dojda do władzy - część gospodarcza, „Nowe Pismo” 1934, nr 2, bezpłatny dodatek. Alter w rozdziale Szkic socjalistycznego programu gospodarczego precyzował, że: „Majątek jednostki nie powinien przekraczać sumy 200000 zł. Wszelka nadwyżka zostaje w całości przelana do Funduszu Gospodarki Społecznej”.

72 J.M. Borski, Dyktatura proletariatu, Warszawa 1933, s. 18.

73 Program Polskiej Partii Socjalistycznej przyjęty w Radomiu 2 lutego 1937 r., Warszawa 1937. 
talistycznej odbywać się musi wraz z działaniami mającymi na celu odzyskanie realnego pięcioprzymiotnikowego prawa wyborczego. Nie sposób nie wymienić w końcu najważniejszego ustępu wspomnianego programu, ukazującego expressis verbis, że nawet w oficjalnej narracji partyjnej ujawniały się wciąż pewne fascynacje rozwiązaniami autorytarnymi. Omawiając zadania przyszłego rządu robotniczo-włościańskiego, wskazano, że

Rząd ten po przełamaniu oporu sił reakcji i faszyzmu wszelkimi rozporządzalnymi środkami, gdyby nawet one musiały w okresie przejściowym przybrać charakter czasowej dyktatury, zapewni masom wolność i najszerszy samorząd, autonomię mniejszościom [...] demokratyzację administracji państwowej ${ }^{74}$.

Fragment ten wyraźnie ilustruje, że nie wyzbyto się całkowicie tęsknoty za rozwiązaniami doraźnymi, o których to pisał w latach trzydziestych Norbert Barlicki. Przyjęcie takiej postaci programu było wyrazem porażki lewicowego nurtu w obrębie partii, liderzy zaś ugrupowania wprost wskazywali na znaczenie przewagi legislatywy nad egzekutywą, poszanowanie zasad prawa wyborczego czy też efektywny samorząd terytorialny.

Egzemplifikacją swoistych wątpliwości doktrynalnych dotyczących pochwały stosowania metod autorytarnych zarówno w teorii, jak i praktyce partyjnej mogą być właśnie rozważania podjęte w 1934 roku przez Norberta Barlickiego. Jego ewolucja poglądów ustrojowych i zapatrywań na metody realizacji zamierzeń programowych ugrupowania może być probierzem problemów, z którymi borykało się kierownictwo partii przy utrzymaniu zasad programowych partii określonych na początku lat dwudziestych. Jego poglądy po maju 1926 roku zdominowane były przeświadczeniem o konieczności przeciwstawienia się rządom piłsudczyków. Reformizm CKW PPS po 1928 roku w poglądach Norberta Barlickiego podlegał stopniowej deprecjacji i zastąpił przekonanie o możliwości czy też wręcz konieczności sięgnięcia po środki bliższe lewicy rewolucyjnej. To zaś ewidentnie wskazywało na przesunięcie się Norberta Barlickiego na lewe skrzydło PPS. Świadomość konieczności zaostrzenia postawy opozycyjnej wobec obozu sanacyjnego zrodziła się u Barlickiego już wcześniej, choć nie w tak dojrzałej formie. W 1928 roku w sprawozdaniu z wystąpienia w dyskusji nad referatem o sytuacji politycznej na XXI Kongresie PPS z dnia 3 listopada 1928 roku podkreślał z jednej strony zasadność dalszej walki politycznej metodami parlamentarnymi: „przewidujemy moment, kiedy będziemy mogli naszą Konstytucję poprawić, sprowadzić parlament do jednoizbowości"75, z drugiej zaś uwypuklał konieczność likwidacji systemu rządów pomajowych.

74 Ibidem, s. 11.

75 N. Barlicki, Sprawozdanie z wystapienia w dyskusji nad referatem o sytuacji politycznej na XXI kongresie PPS 3 listopada 1928 r., [w:] idem, Wybór przemówień i artykułów z lat 1918-1939, zeb. i wstęp J. Tomicki, Warszawa 1964, s. 168. 
W słynnym, opublikowanym w roku 1933 na łamach „Robotnika”, artykule wymownie zatytułowanym Mea culpa Barlicki dokonał swoistego rozliczenia z efektywnością czy też raczej jej brakiem w ruchu socjalistycznym po pierwszej wojnie światowej. Zarzucił on zarówno ugrupowaniom robotniczym, jak i włościańskim bezwład i apatię, które z kolei wynikały z „przedwczesnego przerwania procesu rewolucyjnego"76. O radykalizacji postawy Barlickiego świadczy między innymi semantyka jego wypowiedzi, objawiająca się stosowaniem takich określeń, jak przykładowo ,prawdziwy rewolucjonista”. Wspomniany artykuł nie zawiera rzecz jasna ani wezwania do bojkotu struktur państwa polskiego, ani też nie zachęca wprost do podjęcia działań rewolucyjnych. Jest raczej próbą diagnozy, dlaczego socjalistom nie udało się wyzyskać sprzyjającego realizacji ich programu okresu powojennego. Pisał on: „Gdzież podziała się siła (oczywiście ludowych mas), która sprawiwszy tyle, nie potrafiła rezultatów własnego zwycięstwa zachować? Czyżby zamarło w niej tętno rewolucyjne i czyżby się stała bezwładnym balastem w procesie dziejowym?"77. Znamienne, że Norbert Barlicki, do 1931 roku przewodniczący CKW PPS i lider warszawskiego OKR, odpowiedzi na postawione przez siebie pytania nie udzielił. Zdaniem Jana Tomickiego „Barlicki, odsłaniając przed klasą robotniczą skutki antyrewolucyjnej polityki PPS, pokazując gorzką prawdę lat 1918-1919, zdobył się niewątpliwie na akt dużej odwagi cywilnej"78.

Próbując odpowiedzieć na pytanie, dlaczego fascynacje autorytarnymi metodami sprawowania władzy i sięgnięcia po nią środkami rewolucyjnymi w dłuższej perspektywie nie zyskały uznania przez władze partii i miały charakter efemeryczny, pamiętać należy, że oś sporów programowych w obrębie PPS determinowana była sytuacją polityczną na lewej stronie sceny politycznej. Polska Partia Socjalistyczna nieustannie musiała występować przeciwko Komunistycznej Partii Polski i jej licznym organizacjom satelickim. Komuniści, jak wiadomo, nie wzdragali się przed stosowaniem terroru, zamachów i prowokacji w celu wywołania tak pożądanej przez nich rewolucji. Karol Sacewicz trafnie określał sytuację na lewicy jako wojnę:

Była to wojna między ideą niepodległości a rewolucją, między dążeniami do przeprowadzenia zmian metodami demokratycznymi a parciem do wywołania za wszelką cenę rewolucji, między krytyką rządów bolszewickich a lansowaniem ich jako antidotum na wszystkie problemy robotników $[\ldots]^{79}$.

76 N. Barlicki, Mea culpa, [w:] ibidem, s. 198.

77 Ibidem.

78 J. Tomicki, Norbert Barlicki, s. 298. Pamiętać należy, że na przewartościowanie poglądów N. Barlickiego na kwestie taktyki partyjnej, powodujące przesunięcie się tego działacza ku lewicy socjalistycznej, wpływ miało bez wątpienia rozgoryczenie spowodowane pobytem w twierdzy brzeskiej oraz skazanie na karę pozbawienia wolności w tak zwanym procesie brzeskim liderów Centrolewu. Zaznaczyć trzeba, że zasądzonemu wyrokowi Barlicki się poddał i w przeciwieństwie do innych działaczy nie zdecydował się udać na emigrację.

${ }^{79}$ K. Sacewicz, Polska Partia Socjalistyczna wobec Komunistycznej Partii Robotniczej Polski. Wypisy z prasy i dokumentów, t. 1. 1918-1928, Olsztyn 2014, s. 8. 
Nic też dziwnego, że czołowi teoretycy PPS musieli nieustannie podkreślać odrębność celów politycznych ugrupowania i taktyki partyjnej od metod lewicy rewolucyjnej oraz przeciwstawiać się tendencjom do nawiązania współpracy $\mathrm{z}$ komunistami.

Polska Partia Socjalistyczna w okresie Drugiej Rzeczypospolitej była ugrupowaniem ewolucjonistycznym, demokratycznym, stojącym zasadniczo w opozycji do idei państwa autorytarnego. Liderzy partii odcinali się od rewolucyjnego radykalizmu, jakże charakterystycznego dla socjalistów w okresie burzliwych działań 1905 roku. Wypowiadali się przeciwko zarządzaniu życiem gospodarczym przez organy państwa, tym samym stając w opozycji do koncepcji etatystycznych lansowanych przez część obozu pomajowego ${ }^{80}$. Opowiadali się za koncepcją rządów prawa, czynnikiem nadrzędnym było dla nich realne funkcjonowanie systemu demokracji parlamentarnej, co zasadniczo przyczyniło się do szybkiego przejścia na pozycje opozycyjne względem środowisk skupionych wokół Józefa Piłsudskiego.

\section{Bibliografia}

XVII Kongres PPS, „Trybuna” 29 maja 1920.

Ajnenkiel A., Parlamentaryzm II Rzeczypospolitej, Warszawa 1975.

Alter W., Gdy socjaliści dojda do władzy - czesść gospodarcza, Nowe Pismo" 1934, nr 2, bezpłatny dodatek.

Bäcker R., Problematyka państwa w polskiej myśli socjalistycznej lat 1918-1948, Toruń 1994.

Barlicki N., Wybór przemówień i artykułów z lat 1918-1939, zeb. i wstęp J. Tomicki, Warszawa 1964.

Bobrowski E., Wystapienie dr Emila Bobrowskiego z P.P.S. C.K.W., Kraków 1929, druk ulotny.

Borski J.M., Dyktatura proletariatu, Warszawa 1933.

Borski J.M., Etatyzm, „Robotnik” 27 stycznia 1929.

Borski J.M., Ich etatyzm, „Robotnik” 31 sierpnia 1929.

Chwedoruk R., Ruchy i myśl polityczna syndykalizmu w Polsce, Warszawa 2011.

Ciołkosz A., Ciołkosz L., Zarys dziejów socjalizmu polskiego, Londyn 1972, t. 2.

Daszyński I., Tymczasowy Rząd Ludowy Republiki Polskiej w Lubinie, [w:] P.P.S. Wspomnienia z lat 1918-1939, red. J. Czerski et al., Warszawa 1987.

Dubois S., Wobec sytuacji pomajowej, [w:] Wybór artykułów i przemówień, Warszawa 1988.

80 Wspomnieć należy wypowiedź Zygmunta Zaremby podczas obrad XXI Kongresu PPS odbywającego się w listopadzie 1928 roku w Dąbrowie Górniczej i Sosnowcu. Zaremba podkreślił wówczas współwystępowanie w gospodarce dwóch zjawisk: osłabienia kapitału indywidualnego oraz rosnącej roli państwa w sprawach gospodarczych. „Polityka etatystyczna państwa — powiedział Zaremba — robiona jest pod naciskiem życia wobec braku inicjatywy prywatnej". Zwracał uwagę zebranych uczestników zjazdu na pozorność sanacyjnego etatyzmu, który jego zdaniem był niewiarygodny. Czynił zarzut, że: „Przedsiębiorstwa państwowe, które mogłyby stać się terenem świadomej polityki gospodarczej, wykonują politykę prywatnego kapitału. [...] etatyzm kapitalistyczny, uprawiany przez państwo [...] nie może nas zadowalać”. Zob. Sprawozdanie z XXI Kongresu PPS, s. 67-68. 
Dziewulski K., Spór o etatyzm 1919-1939, Warszawa 1981.

Gajzler A.M., Organizacja Młodzieży Towarzystwa Uniwersytetu Robotniczego (1923-1936). Model młodzieżowego ruchu kulturalno-oświatowego, Kraków 1993.

Głowacki B., Polityka Polskiej Partii Socjalistycznej 1929-1935, Warszawa 1979.

Gołębiowski J., Gospodarcza rola państwa w programach i publicystyce Polskiej Partii Socjalistycznej 1918-1939, [w:] W stulecie polskiego ruchu robotniczego: studia i rozprawy, red. J. Gołębiowski, Kraków 1982.

Hass L., Kształtowanie się lewicowego nurtu w Polskiej Partii Socjalistycznej na tle sytuacji wewnatrzpartyjnej (listopad 1923-maj 1926), „Kwartalnik Historyczny” 1961, nr 1.

Jodko-Narkiewicz W., Objaśnienie programu Polskiej Partii Socjalistycznej, Kraków 1908.

Leinwald A., PPS a sprawa niepodległości Polski, [w:] Stulecie polskiej partii politycznej 18921992, red. M.M. Drozdowski et al., Warszawa 1993.

Liebermann H., Przewrót majowy 1926 r., [w:] P.P.S. Wspomnienia z lat 1918-1939, red. J. Czerski et al., Warszawa 1987.

Kowalski W., Koncepcje ustrojowe izby wyższej parlamentu w II Rzeczypospolitej, Warszawa 2014.

Kowalski W., Stanowisko Polskiej Partii Socjalistycznej wobec zamachu majowego w 1926 roku, „Studia nad Autorytaryzmem i Totalitaryzmem” 40, 2018, nr 2.

Kulesza W.T., Koncepcje ideowo-polityczne obozu rzadzacego w Polsce w latach 1926-1935, Wroclaw 1985.

Manifest Tymczasowego Rządu Ludowego Republiki Polskiej z dnia 7 listopada 1918 r., Lublin-Kraków 1918.

Michałowski S., Idea niepodległego państwa w myśli politycznej Polskiej Partii Socjalistycznej (1892-1923, „Rocznik Lubelski” 33-34, 1991-1992.

Michałowski S., Myśl polityczna Polskiej Partii Socjalistycznej (1918-1939), Lublin 1994.

Michałowski S., Polscy socjaliści, [w:] Więcej niz niepodległość. Polska myśl polityczna 1918-1939, red. J. Jachymek, W. Paruch, Lublin 2001.

Niedziałkowski M., Mieczysław Niedziałkowski o demokracji i parlamentaryzmie, Warszawa 1996.

Niedziałkowski M., Teoria i praktyka socjalizmu wobec nowych zagadnień, Warszawa 1926.

Niedziałkowski M., Wczoraj i jutro, „Robotnik” 1 stycznia 1929.

Odezwa Warszawskiego Komitetu Robotniczego PPS z dnia 3 maja 1906 r., Warszawa 1906, druk ulotny.

Pejaś E., Myśl polityczna Kazimierza Czapińskiego w latach 1918-1939, Warszawa 2017.

Piskała K., Ku Rzeczypospolitej Socjalistycznej. Studium z dziejów myśli socjalistycznej PPS (19291939), Łódź 2017.

Posner S., Jakim powinien być socjalista?, [w:] Kalendarz robotniczy PPS na rok 1921, Warszawa 1921.

Posner S., W obronie demokracji. Przemówienie senatora Stanisława Posnera na posiedzeniu plenarnym Senatu w dniu 31 lipca 1926 roku, Warszawa 1926.

Potkański W., Terroryzm na usługach ugrupowań lewicowych i anarchistycznych $w$ Królestwie Polskim do 1914 roku, Warszawa 2014.

Program Polskiej Partii Socjalistycznej z 1910 roku, Warszawa 1910.

Program Polskiej Partii Socjalistycznej uchwalony na XVII Kongresie w Warszawie w dniach 2125 maj 1920, Warszawa 1920.

Program Polskiej Partii Socjalistycznej z 2 lutego 1937 roku, Warszawa 1937.

Reger T., Socjaliści a niepodległość Polski, Kraków 1919.

Sacewicz K., Polska Partia Socjalistyczna wobec Komunistycznej Partii Robotniczej Polski. Wypisy z prasy i dokumentów, t. 1. 1918-1928, Olsztyn 2014.

Sprawozdanie stenograficzne Sejmu Ustawodawczego z dnia 27 marca 1919 r., Warszawa.

Sprawozdanie stenograficzne z 136 posiedzenia Senatu w dniu 31 lipca 1926 r., Warszawa.

Studia nad Autorytaryzmem i Totalitaryzmem 41, nr 3, 2019

(C) for this edition by CNS 
Sprawozdanie z działalności Towarzystwa Uniwersytetu Robotniczego za rok 1927 i 1928, Warszawa 1929.

Sprawozdanie z XXI Kongresu PPS. Dąbrowa Górnicza-Sosnowiec, (1-go, 2-go, 3-go i 4-go listopada 1928 roku), Warszawa 1928.

Stańczyk J., Wplyw politycznej organizacji klasy robotniczej na akcje zawodowe, „Robotnik” 9 stycznia 1929.

Śliwa M., Dyktatura proletariatu w publicystyce i programach Polskiej Partii Socjalistycznej, „Czasopismo Prawno-Historyczne” 31, 1979, z. 1.

Śliwa M., Instytucja Izby Pracy w programie społeczno-politycznym Polskiej Partii Socjalistycz$n e j$, ,Studia Historyczne” 1980, nr 4.

Śliwa M., Ludowcy i socjaliści w parlamencie II Rzeczypospolitej, Warszawa 1995.

Śliwa M., Polska myśl polityczna w I połowie XX wieku, Wrocław 1993.

Śliwa M., Polska myśl socjalistyczna 1918-1948, Wrocław 1988.

Terroryści bolszewiccy, „Naprzód” 25 lipca 1925.

Tomasiewicz J., Naprawa czy zniszczenie demokracji? Tendencje autorytarne i profaszystowskie w polskiej myśli politycznej 1921-1935, Katowice 2012.

Tomicki J., Norbert Barlicki, Warszawa 1968.

Tomicki J., Polska Partia Socjalistyczna 1892-1948, Warszawa 1983.

Towarzysze! Obywatele! Warszawa ma uczcić obchodem uroczysta rocznice 3 Maja!, druk ulotny, Warszawa 1916.

Uczestnictwo socjalizmu w rzadach państwem, „Przedświt. Dziennik socjalistyczny” 14 listopada 1928.

Urbanowicz A., Uspołecznienie własności i wizja nowego ładu gospodarczego w polskiej myśli socjalistycznej (1918-1939), Gorzów Wielkopolski 2013.

Więch K., PPS w pierwszych latach parlamentaryzmu 1921-1923, Warszawa 1987.

Wnioski na IV Kongres Delegatów Związków w Warszawie, „Robotniczy Przegląd Gospodarczy” 12 maja 1935, dodatek.

Wroński A., Objaśnienie programu Polskiej Partii Socjalistycznej, Kraków 1908.

Zackiewicz G., Syndykaliści w obozie „rewolucji majowej” (1926-1935), „Studia Podlaskie” 16, 2006.

Zackiewicz G., Syndykalizm w polskiej refleksji i rzeczywistości politycznej I połowy XX wieku, Kraków 2013.

Zackiewicz G., Z dziejów syndykalizmu polskiego: geneza i działalność Generalnej Federacji Pracy (1928-1931), „Dzieje Najnowsze” 2009, z. 1.

Zaremba Z., Bezdroża kapitalizmu i drogowskazy przyszłości, Warszawa 1933.

Zaremba Z., P.P.S. w Polsce niepodległej 1918-1932, [w:] Księga Jubileuszowa Polskiej Partii Socjalistycznej 1892-1932, red. A. Krieger et al., Warszawa 1933.

Zdanowski A., Etatyzm, „Robotniczy Przegląd Gospodarczy” 1929, nr 2.

Żarnowska A., Geneza rozłamu w Polskiej Partii Socjalistycznej 1904-1906, Warszawa 1965.

\section{BETWEEN DEMOCRATISM AND AUTHORITARIANISM - FORMATION OF THE POLITICAL PROGRAM OF THE POLISH SOCIALIST PARTY BEFORE AND AFTER MAY 1926}

\section{Summary}

The article presents the political debate which took place within the Polish Socialist Party after 1905, regarding the selection of real means to achieve its political goals. The Polish Socialist Party in the period of the Second Polish Republic was an evolutionist and democratic organiza- 
tion, standing in opposition to the ideas of an authoritarian state. The party leaders dissented from achieving political program objectives through methods typical of revolutionary radicalism. The authoritarian fascinations of the May 1926 coup d'etat in the long-term did not lead to a re-evaluation of the political program adopted at the moment of independence.

Keywords: Polish authoritarianism in the Second Polish Republic, democracy, political program of the Polish Socialist Party, May 1926 coup d'etat, parliamentarism in the Second Polish Republic, security.

Wawrzyniec Kowalski

wawrzyniec.kowalski@wat.edu.pl 